Artikel Penelitian

\title{
Reaktor Nitrifikasi Biofilter Untuk Air Limbah Sisa Makanan Dan Feses Ikan
}

\author{
Benny Dwika Leonanda, Yegi Zolanda \\ Jurusan Teknik Mesin, Fakultas Teknik, Universitas Andalas, Kampus Limau Manis, Padang 25163, Indonesia
}

\section{INFORMASIARTIKEL}

\section{Sejarah Artikel:}

Diterima Redaksi: 02 Februari 2018

Revisi Akhir: 22 Maret 2018

Diterbitkan Online: 26 April 2018

\section{KATA KUNCI}

Nitrifikasi

Reaktor

Air Limbah

KORESPONDENSI

E-mail: benny@ft.unand.ac.id

\begin{abstract}
A B $\mathbf{S}$ T $\mathbf{R}$ A $\mathbf{C}$ T
In the sector of freshwater fish breeding, many fish are found dead suddenly. The cause of the fish death suddenly can occur due to toxic water or low oxygen content in the water. In Maninjau Lake, fish died suddenly because of low oxygen content in the water. The low oxygen content in water is caused by increased ammonia from food waste and fish feces. Results in active bacteria and metamolizes by absorbing oxygen in the water.
\end{abstract}

One way to overcome this is to react with a biofilter reactor. In operation, the reactor is given an inlet debit of 1 to $3 \mathrm{lt} / \mathrm{min}$ for the test material and the inlet is worth 10 to $20 \mathrm{lt} / \mathrm{min}$. The highest reactor effectiveness is at the debit of test material $2 \mathrm{lt} / \mathrm{min}$ and the debit of air $15 \mathrm{lt} / \mathrm{min}$. It is characterized by changes in the $\mathrm{pH}$ of water that returns to normal.

\section{PENDAHULUAN}

Senyawa yang sangat penting dalam kehidupan adalah nitrogen, karena nitrogen merupakan salah satu nutrient utama yang berperan dalam pertumbuhan organisme hidup. Nitrogen juga merupakan komponen dasar protein yang keberadannya digunakan untuk memproduksi sel bagi hewan dan tumbuh-tumbuhan yang berada di perairan.

Sebesar $78 \%$ gas yang ada di udara atmosfer merupakan nitrogen. Pada umumnya gas nitrogen ini tidak dapat dipergunakan secara langsung oleh makhluk hidup, hanya beberapa organisme khusus yang dapat mengubahnya ke dalam bentuk organik nitrogen dan proses yang terjadi dinamakan fiksasi.
Nitrogen terlarut dapat diikat oleh sejumlah bakteri dan alga yang berada di lingkungan perairan. Tumbuhan dan alga berperan sebagai pensintesa nitrogen organik yang berguna untuk hewan sebagai sumber nitrogennya. Pada proses metabolismenya, nitrogen yang berada di dalam tubuh hewan akan di buang keluar dari tubuh dalam bentuk senyawa kimia. Kemudian senyawa tersebut di proses oleh mikroorganisme dan nitrogen tersebut akan dilepaskan kelingkungan dalam bentuk amoniak. Proses yang sama juga akan terjadi pada hewan dan tumbuhan yang sudah mati dan proses ini dibantu oleh dekomposer (bakteri pengurai). Amoniak yang timbul akibat ini disebut dengan proses amonifikasi. Amoniak ini sangat berperan penting untuk asimilasi sel baru bagi tumbuhan dan mikroorganisme dan akan memberikan lebih banyak nitrogen organik. Proses 
pemanfaatan ini terus berulang di pada setiap makhluk hidup dan proses ini membentuk siklus yang disebut dengan siklus nitrogen.

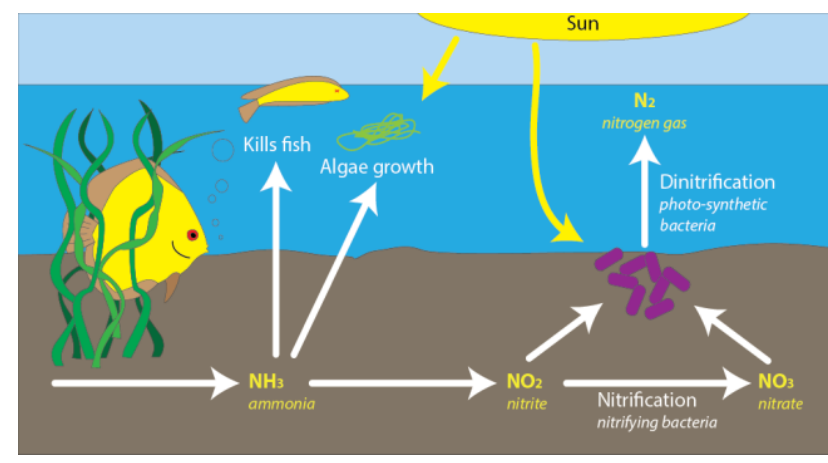

Gambar 1. Siklus nitrogen di perairan

Siklus nitrogen dapat dijelakan dalam reaksi kimia sebagai berikut :

$$
4 \mathrm{NO}_{3}^{-}+8 \mathrm{H}_{2} \mathrm{O} \rightarrow 4 \mathrm{NH}_{3}+4 \mathrm{O}_{2}+4 \mathrm{OH}^{-}
$$

$\mathrm{NH}_{3}+\mathrm{CO}_{2}+$ tumbuhan hijau + cahaya matahari $\rightarrow$ protein

\subsection{Proses Nitrifikasi}

Proses nitrifikasi merupakan proses pengubahan senyawa nitrogen yang berada di alam, proses ini dimulai dari perubahan amoniak $\left(\mathrm{NH}_{4}{ }^{-}\right)$menjadi senyawa nitrit $\left(\mathrm{NO}_{2}^{-}\right)$. Senyawa nitrit ini masih dalam bentuk senyawa yang belum stabil yang kemudian dioksidasi untuk menjadi nitrat $\left(\mathrm{NO}_{3}{ }^{-}\right)$. Dalam melakukan proses ini terdapat berbagai syarat untuk melakukannya, salah satunya ialah udara dan untuk mendapatkan suplai udara yang pas dapat disuplai menggunakan kompresor ataupun blower. Selain dari dibutuhkan bakteri nitrifikasi (nitrifying bacteria). udara juga dibutuhkan bakteri nitrifikasi (nitrifying bacteria).

Secara sederhana, reaksi nitrifikasi adalah sebagai berikut [1].

$\mathrm{aNH}_{4}^{-}+\mathrm{bO}_{2}+\mathrm{cHCO}_{3}^{-} \rightarrow \mathrm{dC}_{5} \mathrm{H}_{7} \mathrm{NO}_{2}+\mathrm{eH}_{2} \mathrm{O}+\mathrm{fNO}_{3}^{-}+\mathrm{gH}_{2} \mathrm{CO}_{3}$

Dimana; a, b, c, d, e, f, g, = koefisien persamaan reaksi
Proses nitifikasi melalui beberapa tahap yakni [1] :

\subsubsection{Tahap Nitritasi}

Tahap nitritasi didefiniskan sebagai tahap oksidasi ion ammonium $\left(\mathrm{NH}_{4}{ }^{+}\right)$menjadi ion nitrit $\left(\mathrm{NO}_{2}{ }^{-}\right)$ yang dilaksanakan oleh bakteri nitrosomonas menurut raksi sebagai berikut :

$$
\mathrm{NH}_{4}^{+}+\frac{1}{2} \mathrm{O}_{2}+\mathrm{OH}^{-} \rightarrow \mathrm{NO}_{2}^{-}+\mathrm{H}^{+}+2 \mathrm{H}_{2} \mathrm{O}+59,4 \mathrm{Kcal}
$$

Nitrosomonas

Reaksi ini memerlukan 3.34 gram $\mathrm{O}_{2}$ untuk mengoksidasi 1 gram nitrogen menjadi nitrit.

\subsubsection{Tahap Nitritasi}

Tahap nitrasi didefinisikan sebagai tahap oksidasi ion nitrit menjadi ion nitrat $\left(\mathrm{NO}_{3}{ }^{-}\right)$yang dilaksanakan oleh bakteri nitrobacter menurut reaksi berikut :

$$
\begin{gathered}
\mathrm{NO}_{2}{ }^{-}+\frac{1}{2} \mathrm{O}_{2} \rightarrow \mathrm{NO}_{3}{ }^{-}+18 \mathrm{Kcal} \\
\text { Nitrobacter }
\end{gathered}
$$

Reaksi ini memerlukan 1.14 gram $\mathrm{O}_{2}$ untuk mengoskidasi 1 gram nitrogen menjadi nitrat.

\subsection{Faktor Pengontrol Proses Nitrifikasi}

Selain dari kedua bakteri nitfrikisi ada beberapa faktor yang dilakukan untuk pengontrolan proses untuk pengolahan limbah air, yaitu :

\subsubsection{Konsentrasi Oksigen Terlarut}

Proses mitrifikasi merupakan proses aerob, maka keberadaan oksigen sangat penting dalam proses ini. Dengan demikian dibutuhkan batasan DO yang memungkinkan proses ini dapat berjalan dengan baik. Proses nitrifikasi akan berjalan baik jika DO minimum > $1 \mathrm{mg} / \mathrm{l}[2]$. 


\subsubsection{Temperatur}

Kecepatan pertumbuhan bakteri nitrifikasi dipengarui oleh temperatur dan temperatur yang berpengaruh berada pada kisaran $8^{\circ} \mathrm{C}-30^{\circ} \mathrm{C}$, sedangkan temperatur maksimumnya sekitar $30^{\circ} \mathrm{C} .[3]$

\subsection{3. $\mathrm{pH}$}

Pada proses biologi, nitrifikasi dipengaruhi oleh $\mathrm{pH}$. pH maksimum untuk bakteri nitrosomonas dan nitrobacter antar 7.5-8.5 [4]. Proses ini akan terhenti pada $\mathrm{pH}$ di bawah 6.0 [5]

\subsubsection{Intensitas Cahaya Matahari}

Cahaya matahari ini berpengaruh terhadap pertumbuhan mikroorganisme. Jika cahaya matahari terlalu banyak maka akan meyebabkan mikroorganisme mati namun jika kekurangan cahaya matahri akan menyebabkan mikroorganisme tidak tumbuh secara maksimum [3].

\subsection{Reaktor Nitrifikasi}

Pada proses nitrifikasi ada beberapa macam reaktor yang dapat digunakan untuk prosesnya. Reaktor itu dapat terbagi dalam berbagai prinsip kerja, ada reaktor dengan sistem kimia, sistem fisika, dan sistem biologi. Dari semua sistem ini yang paling effisien untuk digunakan adalah reaktor dengan sistem biologi karena prinsip kerjanya yang mudah diterapkan dimasyarakat.

Mikroorganisme yang terdapat pada saringan ini menyababkan kadar oksigen dalam air berkurang terhadap lapisan terdalam dari biofilm sehingga menyababkan terjadinya kondisi anaerobik pada lapisan permukaan media. Media penyangga merupakan salah satu kunci pada proses biofilter. Effektifitas dari suatu media tergantung pada [1] :

a. Luar permukaan, semakin luas permukaan media maka semain besar jumlah biomassa per unit volume.

b. Volume rongga, semakin besar volume rongga kosong maka semakin besar kontak antar substrat dalam air buangan dengan biomassa yang menempel.

\section{METODOLOGI}

\subsection{Tahap Perancangan Reaktor}

Rancangan reaktor biofilter mangadopsi rancangan reaktor biofilter [1], dengan menyesuaikan bahan uji berupa air limbah dari sisa makanan dan feses ikan :

a. Bejana (reaktor)

Bejana reaktor berfungsi sebagi tempat mengalirkan bahan uji. Reaktor dirancang dalam bentuk balok yang terbuat dari acrylic dengan panjang $200 \mathrm{~mm}$, lebar $200 \mathrm{~mm}$, tinggi $100 \mathrm{~mm}$. tutup dari reaktor dilapisi dengan dengan shell karet agar mencegah kebocoran.

b. Bejana (sampel uji)

Bejana sampel uji berfungsi sebagai tempat penampungan dari bahan uji yang akan dialirkan ke reaktor.

\section{c. Penyangga}

Penyangga terdapat di dalam reaktor biofilter yang berfungsi sebagai tempat untuk menahan saringan.

\section{d. Saringan}

Saringan ini merupakan tempat untuk berkembangnya mikroorganisme dan ukuran dari saringan mengikuti ukuran dari bejana.

e. Katup

Katup berfungsi sebagai tempat keluar nya air dari bahan uji. Katup ini merupakan bagian terakhir dari aliran air sebelum keluar dari reaktor.

\subsection{Skema Alat Uji}

Adapun skema dari alat uji yang telah dijelaskan dapat dilihat pada Gambar 2. Di dalam rekator dipasang tiga buah sekat terbuat dari bahan polimer dan dilapisi oleh sabut kelapa sebagai bahan organic untuk tempat pertumbuhan bakteri. Pada masing-masing ruangan di dalam reaktor tersebut dialiri oleh udara dengan distribusi seimbang dan mendapat masukan udara sama besar. Sementara air dimasukan ke dalam reaktor 
melajui saluran dan dibalikan ke dalam kolam penampung.

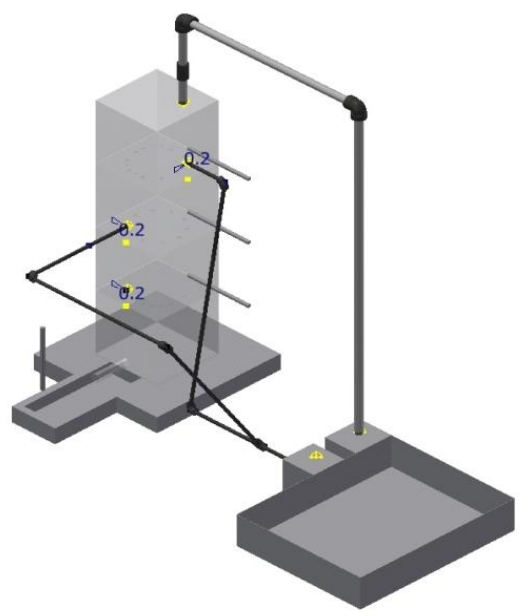

Gambar 2. Skema alat uji

Temperatur diukur pada masing-masing ruangan, ditandai pada bagian teratas sebagai $\mathrm{T}_{1}$, dan ruang berikutnya ditandai berturut-turut dengan $T_{2}, T_{3}$, dan $\mathrm{T}_{4}$.

\section{HASIL DAN PEMBAHASAN}

Pada Gambar 3 s/d 5 diperlihatkan variasi temperatur akibat perubahan laju aliran bahan uji.

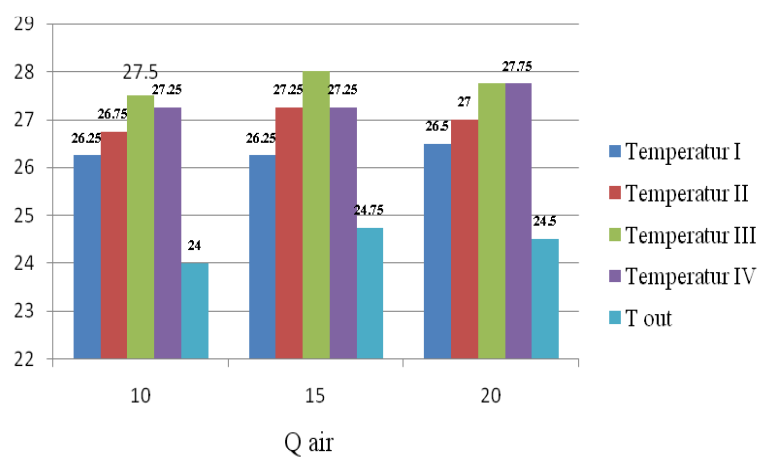

Gambar 3. Grafik Pengaruh Debit Udara Terhadap Temperatur pada laju aliran air1 Liter / min

Pada Gambar 3 diperlihatkan terjadi kenaikan temperatur disetiap tingkat reaktor. Temperatur perlahan-lahan naik sampai pada kondisi maksimum pada ruangan ke tiga, dan kemudian turun pada ruang ke empat $\left(\mathrm{T}_{4}\right)$, dan kembali ke temperatur ruangan pada $T_{\text {out }}$.

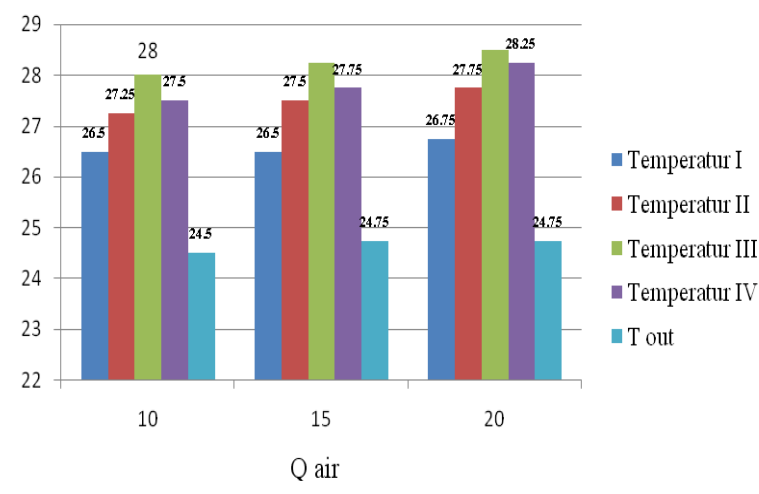

Gambar 4. Grafik Pengaruh Debit Udara Terhadap Temperatur pada laju aliran air 2 Liter / min

Pengaruh aliran udara $\left(\mathrm{Q}_{\text {air }}\right)$ dapat terlihat dengan jelas pada Gambar 3. Kondisi optimal dapat dilihat pada debit 15 lt/min. Pada Gambar 4 diperlihatkan variasi temperature terhadap pertambahan debit udara ke dalam reactor untuk laju aliran air 2 Liter/min. Terjadi peningkatan temperatur di dalam reaktor dengan bertambahnya aliran udara.

Pada Gambar 5 diperlihatkan variasi temperature terhadap pertambahan debit udara ke dalam reactor untuk laju aliran air 3 Liter/min. Peningkatan debit aliran tidak membawa perubahan terhadap temperature di dalam ruangan seperti diperlihatkan pada Gambar 5.

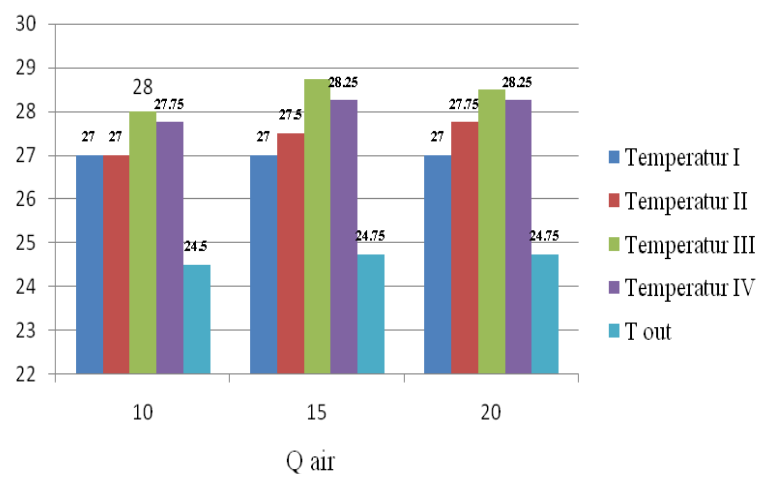

Gambar 5. Grafik Pengaruh Debit Udara terhadap Temperatur pada laju aliran air 3 Liter / min 
Pada Gambar 6 diperlihatkan pengaruh debit udara terhadap peningkatan $\mathrm{pH}$ aliran pada aliran air 1 1t/min. Pada Gambar tersebut dapat dilihat tidak ada perubahan $\mathrm{pH}$ air pada saat masuk dan keluar dari reaktor.

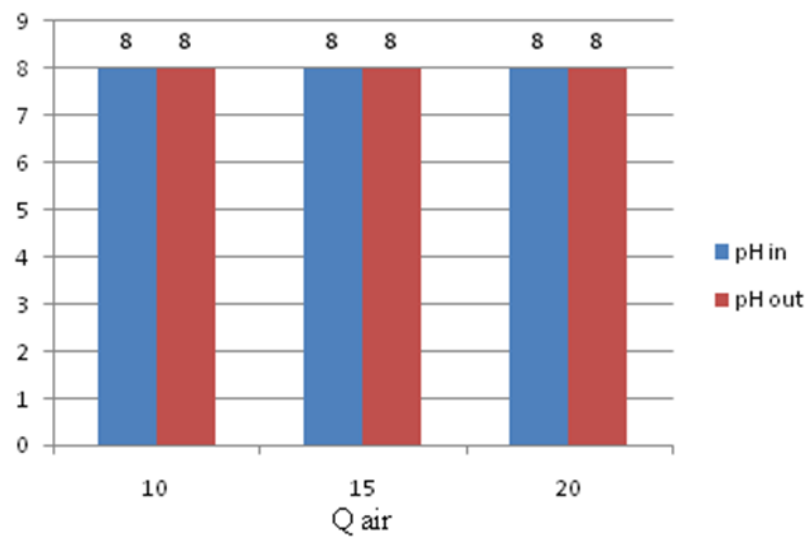

Gambar 6. Grafik Pengaruh Debit Udara Terhadap pH Saat Bahan Uji 1 Liter / min

Gambar 7 memperlihatkan pengaruh debit udara terhadap peningkatan $\mathrm{pH}$ aliran pada aliran air 2 Liter/min. Berdasarkan hasil pada Gambar tersebut dapat dilihat tidak ada perubahan $\mathrm{pH}$ air pada saat debit udara 10 Liter/min dan 20 Liter/m. Akan tetapi perubahan $\mathrm{pH}$ masuk dan keluar dari reaktor terjadi saat debit udara 15 Liter/min.

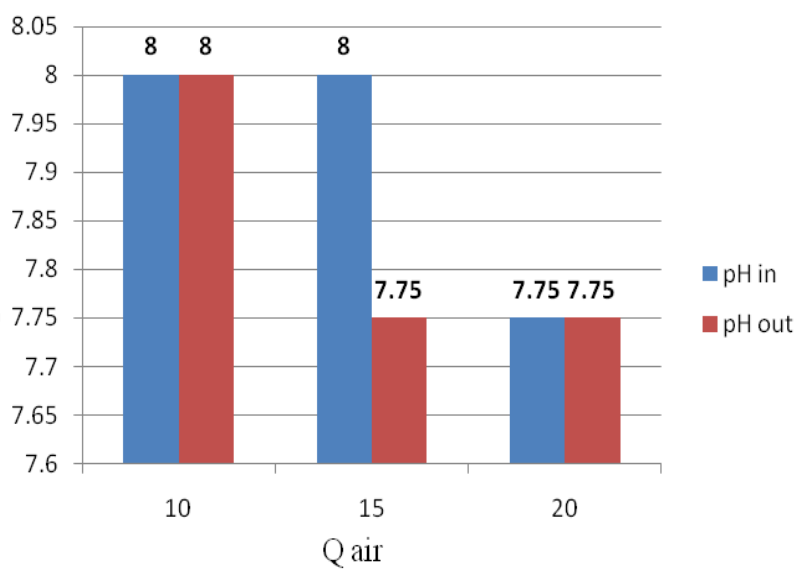

Gambar 7. Grafik Pengaruh Debit Udara Terhadap pH Saat Bahan Uji 2 Liter / min

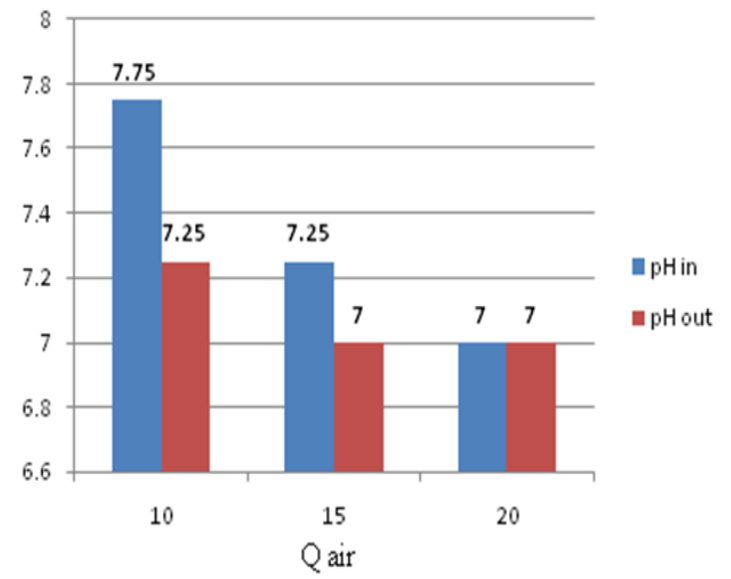

Gambar 8. Grafik Pengaruh Debit Udara Terhadap $\mathrm{pH}$ Saat Bahan Uji 3 Liter / min

Untuk laju aliran air 3 Liter/min, perubahan $\mathrm{pH}$ diperlihatkan pada Gambar 8. Pada gambar tersebut terlihat bahwa terjadi perubahan $\mathrm{pH}$ untuk laju aliran udara 10 dan 15 Liter/min.

Berdasarkan hasil yang diperoleh terlihat bahwa pertambahan aliran air ke dalam reaktor membuat $\mathrm{pH}$ air berkurang. Sehingga dapat dikatakan bahwa proses nitrifikasi berlangsung lebih cepat dengan bertambahnya aliran air ke dalam reaktor.

\section{KESIMPULAN DAN SARAN}

- Terdapat peningkatan termperatur pada proses nitrifikasi sejalan dengan bertambahnya debit aliran air ke dalam reaktor.

- Terjadi penurunan $\mathrm{pH}$ air ketika aliran air kedalam reaktor semakin bertambah. Proses nitrifikasi dapat dikatakan bertambah cepat dengan bertambahnya aliran air ke dalam reaktor.

- Proses nitrifikasi pada reaktor biofilter memiliki pengaruh pada saat debit bahan uji bernilai $2 \mathrm{lt} / \mathrm{min}$ dan debit udara bernilai $15 \mathrm{lt} / \mathrm{min}$.

- Untuk penelitian berikutnya sebaiknya dilakukan penelitian mengenai bagaimana pengaruh debit bahan uji dan debit udara 
terhadap karakteristik mekanik dari denitrifikasi reaktor biofilter.

\section{DAFTAR PUSTAKA}

[1] R. Marsidi, "Proses Nitrifikasi Dengan Sistem Biofilter untuk Pengolahan Air Limbah Yang Mengandung Amoniak Konsentrasi Tinggi," Jurnal Teknologi Lingkungan, Vol.3, No. 3, 2002.

[2] K. Kida, "Efficient Removal of Organic Matter and $\mathrm{NH}$ from Pot Ale by a Combination of Methane Fermentation and Biological Denitrification and Nitrification Process". Journal of Process Engineering, 1999.
[3] A. Vanzella, "Effect of $\mathrm{CO}$ and light on ammonium and nitrite oxidation by chemolithotrophic bacteria," Department of Biological Sciences and Drinking Water Research Center, Florida International University, University Park, Miami, Florida, 1989.

[4] EPA. 2002. Nitrification. U.S. Environmental Protection Agency Office of Ground Water and Drinking Water Standards and Risk Management Division 1200 Pennsylvania Ave. Washington.

[5] H. A. Painter, "Nixification In The Treannent Of Sewage And Waste Waters," Oxford, 1987 